\title{
The ST2/Interleukin-33 Axis in Hematologic Malignancies: The IL-33 Paradox
}

\author{
Alessandro Allegra ${ }^{1, *,+}+\mathbb{C}$, Vanessa Innao ${ }^{1}$, Gennaro Tartarisco ${ }^{2}$, Giovanni Pioggia ${ }^{2}$, \\ Marco Casciaro $^{3}$, Caterina Musolino ${ }^{1, \dagger}$ and Sebastiano Gangemi ${ }^{3,+}$ \\ 1 Division of Hematology, Department of Human Pathology in Adulthood and Childhood, \\ University of Messina, 98125 Messina, Italy; vinnao@unime.it (V.I.); cmusolino@unime.it (C.M.) \\ 2 National Research Council of Italy (CNR)-Institute for Biomedical Research and Innovation (IRIB), \\ 98164 Messina, Italy; gennaro.tartarisco@cnr.it (G.T.); giovanni.pioggia@cnr.it (G.P.) \\ 3 School and Division of Allergy and Clinical Immunology, Department of Clinical and Experimental \\ Medicine, University Hospital “G. Martino”, Via Consolare Valeria SNC, 98125 Messina, Italy; \\ mcasciaro@unime.it (M.C.); gangemis@unime.it (S.G.) \\ * Correspondence: aallegra@unime.it; Tel.: +39-09-0221-2364 \\ + These authors contributed equally to this work.
}

Received: 16 July 2019; Accepted: 16 October 2019; Published: 22 October 2019

\begin{abstract}
Interleukin (IL)-33 is a chromatin-related nuclear interleukin that is a component of IL-1 family. IL-33 production augments the course of inflammation after cell damage or death. It is discharged into the extracellular space. IL-33 is regarded as an "alarmin" able to stimulate several effectors of the immune system, regulating numerous immune responses comprising cancer immune reactions. IL-33 has been demonstrated to influence tumorigenesis. However, as far as this cytokine is concerned, we are faced with what has sometimes been defined as the IL-33 paradox. Several studies have demonstrated a relevant role of IL-33 to numerous malignancies, where it may have proand-less frequently-antitumorigenic actions. In the field of hematological malignancies, the role of IL-33 seems even more complex. Although we can affirm the existence of a negative role of IL-33 in Chronic myelogenos leukemia (CML) and in lymphoproliferative diseases and a positive role in pathologies such as Acute myeloid leukemia (AML), the action of IL-33 seems to be multiple and sometimes contradictory within the same pathology. In the future, we will have to learn to govern the negative aspects of activating the IL-33/ST2 axis and exploit the positive ones.
\end{abstract}

Keywords: alarmin; hematologic malignancies; interleukin 33; immune response; tumorigenesis

\section{Introduction}

\subsection{IL-33}

Interleukin (IL)-33 is a component of the IL-1 family, cytokines that maintain a structure of $\beta$-trefoil folds containing 12 antiparallel $\beta$-strands that are organized in a three-fold symmetric configuration [1]. IL-33 was originally reported as a protein amply present in endothelial venules that facilitates the entrance of lymphocytes into lymphoid organs, and was hence called "nuclear factor from high endothelial venules" [2].

It is now recognized that this cytokine is a chromatin-related nuclear interleukin, and that connecting to histones is crucial for IL-33 action [3]. Nuclear IL-33 can act as a transcriptional repressor when overexpressed in cells [4]. IL-33 production can be augmented in the course of inflammation [2,5]. In fact, after cell damage or death, IL-33 is discharged into the extracellular space and operates as an endogenous danger signal that warns the immune cells of the occurred damage. The liberation of IL-33 can be due to necrotic cell death [5]. 
IL-33 is regarded as an "alarmin" able to stimulate several effectors of the immune system, regulating numerous immune responses comprising cancer immune reactions [6,7] (Figure 1).

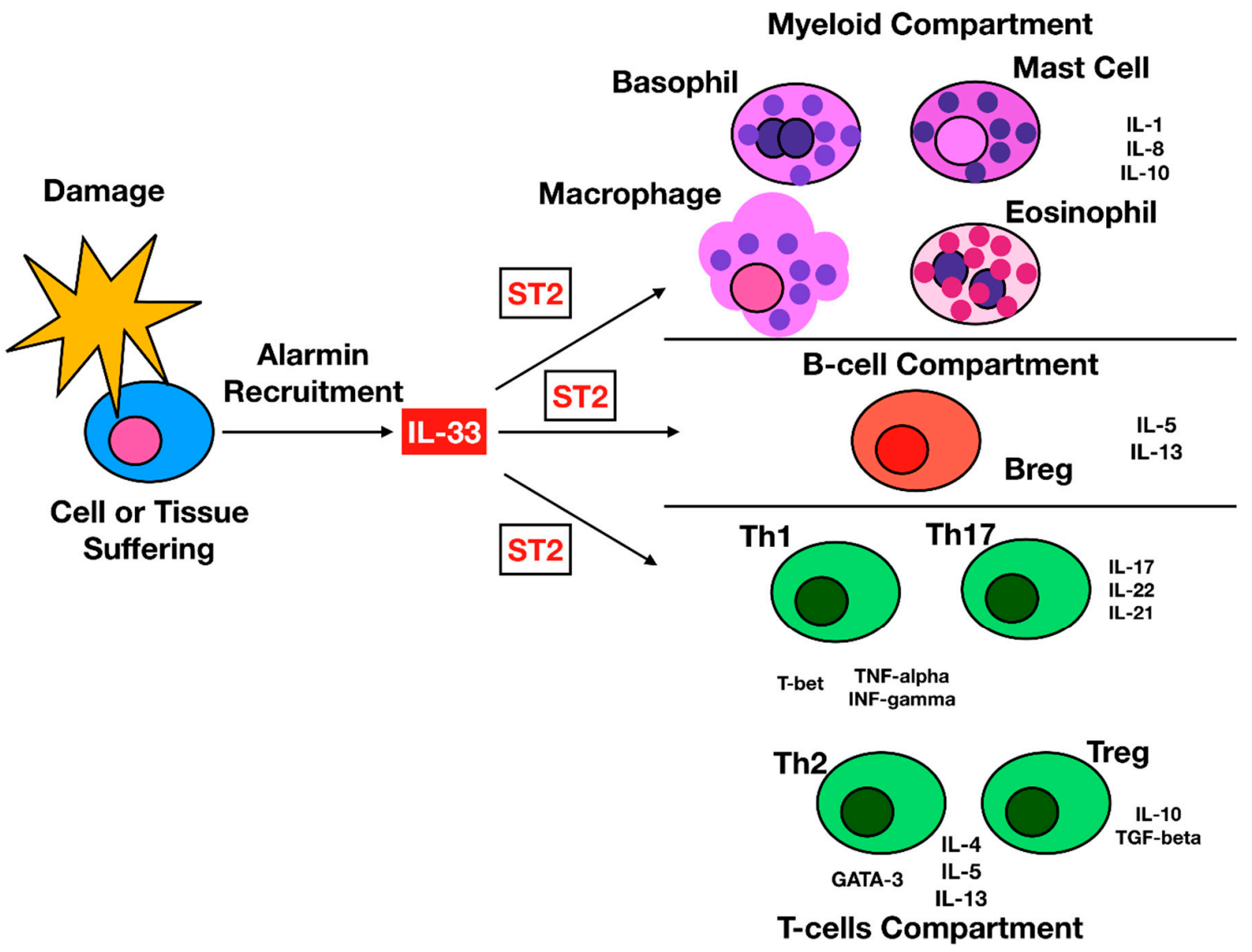

Figure 1. IL-33 Interleukin-33 (IL-33) signaling on immune cells. Tissue and cells damage lead to the release of IL-33 from these cells. IL-33 then signals to many different immune cells, enhancing their function and activating several immune mediators involved in inflammation and immune regulation.

The precise processes which lead to the release of IL-33 are yet not completely known, and it may be different in diverse experimental models. In fact, in addition to the classical damage liberation of IL-33, the cytokine may be released after stimulation of purinergic receptor P2Y2R signaling [8]. Furthermore, alternative splicing-mediated deletion of exon 3 and 4 of IL33 transcripts provoke cytoplasmic delocalization of IL-33 proteins, and this isoform can maintain its capacity to react with its receptor [9].

IL-33 is produced in a full-length configuration ( 270 amino acids), and it gets cleaved by neutrophil serine proteases cathepsin $G$ and elastase once it is released from the nucleus, which increases its activity 10-fold [10]. However, it was largely demonstrated that this activation process is not necessary for IL-33 to exert its function because it has different bioactive forms [2,3,11]. It is of interest that during apoptosis, a type of cell death that does not activate inflammation, IL-33 is deactivated by endogenous caspases [11-13]. A different system able to control IL-33 action is oxidation. Extracellular IL-33 is vulnerable to cysteine oxidation that causes the formation of disulphide bridges, determining conformational modifications that impede the link to its receptor, thus inactivating IL-33 [14].

However, the presence of diverse human full-length mRNA splice variants has been demonstrated, according to the cell type and the disease, and different immune effects are caused by the different molecules $[15,16]$. Moreover, inflammatory proteases from mast cells and other cells can transform full-length IL-33 into shorter structures $(18-21 \mathrm{kDa})$ whose action is 30 -fold more potent than the full-length form. However, the shorter form does not pass into the nucleus as it does not have the nuclear localization signal present in full-length IL-33 [10,17-19]. 


\subsection{The ST2 Receptors}

IL-33 is a ligand of its receptor, which is composed of ST2/IL1RL1 and IL1RAP. It is encoded by Interleukin 1 receptor-like 1 (IL1RL1) that generates four different isoforms via alternative splicing: ST2 ligand (ST2L), sST2, ST2 variant (ST2V), and ST2 ligand variant (ST2LV). ST2L is a membrane receptor that contains an ILI-R1-like intracellular domain, a transmembrane spanning region, and three Ig-likeextracellular domains [20,21]. sST2, a glycosylated protein, is a soluble form of ST2. It does not have the transmembrane domain but includes an extracellular domain analogous to ST2L and nine amino acids at the C-terminal tail [22]. ST2V is similar to SST2 but includes a hydrophobic tail instead of the third Ig-like domain [23,24]. ST2LV is an N-glycosylated and soluble form that does not have the transmembrane domain present in ST2L [25]. ST2L creates a heterodimeric transmembrane receptor complex with the IL1-receptor accessory protein, IL1-RAcP, which is required for signaling after IL-33 binding [26], and sST2 works sequestering extracellular IL-33 (Figure 2).

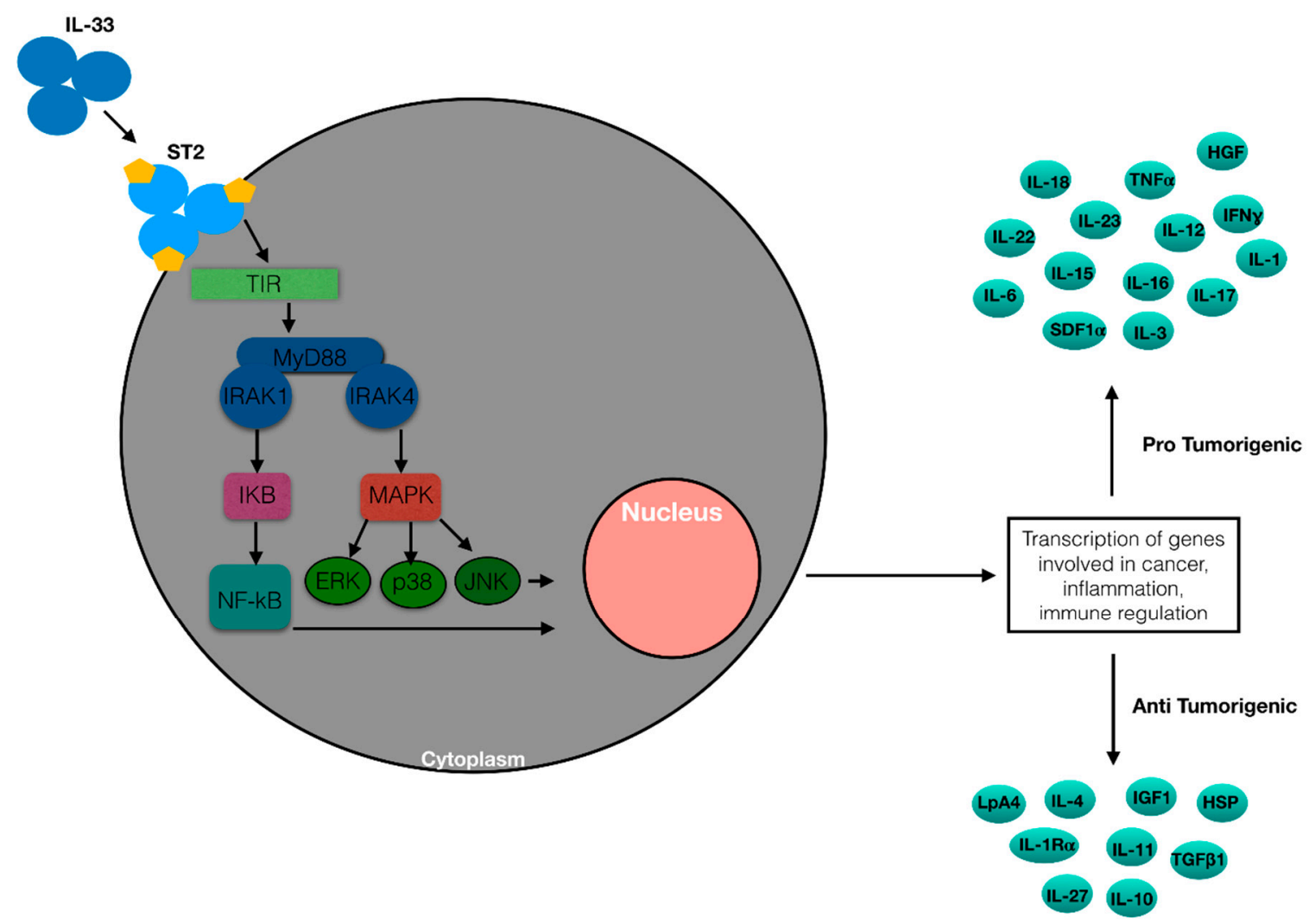

Figure 2. ST2/IL-33 immune cells signaling pathway. IL-33 either binds to the ST2 receptor, recruiting MyD88 to its intracellular domain. MyD88 binding recruits IL-1R-associated kinase (IRAK) 1 and 4, leading to either the NF- $\mathrm{KB}$ or MAPK pathway being activated. Their activations promote inflammatory cytokine expressions. ST2/IL-33 signaling has been shown to promote Treg and immune system cells function and expansion through enhancing TGF- $\beta 1$-mediated differentiation though a p38-dependent mechanism. ST2/IL-33 link activates the transcription of several genes involved in tumorigenesis, inflammation and immune regulation.

Expression of the IL1RL1 gene is controlled by GATA1/2 and estrogen-response elements (EREs) that are found in the distal and proximal promoters that rule ST2L and SST2 expression [27-31].

\subsection{IL-33 Cellular Targets}

Most hematopoietic cells present the ST2 receptor: T helper (Th)1 cells, Th2 cells, innate lymphoid cells 2 (ILC2s), CD8+ T cells, some Treg cells, natural killer (NK) cells, mast cells, B cells, neutrophils, basophils, eosinophils, and myeloid-derived suppressor cells (MDSC) are cells that express high levels 
of ST2. However, nonhematopoietic cells, comprising fibroblasts, epithelial cells, endothelial cells, and dendritic cells (DC), also express ST2 and may respond to IL-33 [32-34].

Regarding the effects of IL-33 on the main cellular effectors, stimulation with IL-33 pushes naïve $\mathrm{CD} 4+\mathrm{T}$ helper cells differentiation toward a Th phenotype [35]. Human CD4+ T cells can have antitumor activity by expressing high amounts of MHC class II and self-antigens on their membrane via secretion of IFN- $\gamma$ [36]. Mousa Komai-Koma et al. demonstrated that IL-33 may increase CD4 ${ }^{+}$Th1 differentiation via a mechanism depending on IL-12 and ST2. IL-33 and IL-12 synergistically augment ST2 expression in early activated CD4 ${ }^{+} \mathrm{T}$ cells, while it is ineffectual on mature Th1 cells [37]. This is because ST2 expression is produced only in early-TCR activated naïve $\mathrm{CD} 4^{+} \mathrm{T}$ cells and is proresively inhibited in mature Th1.

ST2/IL-33 signaling is also able to increase suppressive $\mathrm{CD}^{+}{ }^{+} \mathrm{Foxp}^{+} \mathrm{GATA}^{+}$Treg cells in vivo and in vitro [38]. IL-33-expanded Tregs produce strong suppressor action in several diseases [39].

$\mathrm{ST}_{2}{ }^{+}$Treg increase can be due to IL-33 signaling in DCs, via the generation of IL-2 [40]. In the intestine, IL-33 signaling increases transforming growth factor (TGF)- $\beta 1$-mediated transformation of Treg cells and acts as a signal for Treg accumulation in damaged tissues [41], while in $\mathrm{Apc}^{\mathrm{Min} /+}$ mice, epithelial-derived IL-33 increase the proliferation of ST2 ${ }^{+}$Treg cells [42-44].

Regarding $\mathrm{CD}^{+} \mathrm{T}$ cells, only effector or polarized type 1 cytotoxic $\mathrm{T}$ (Tc1) cells express ST2, while naïve and early activated $\mathrm{CD} 8^{+} \mathrm{T}$ cells lack the receptor [45]. Expression of $\mathrm{ST} 2$ in $\mathrm{CD} 8^{+} \mathrm{T}$ cells is controlled by T-bet, a master transcription regulator, and it has been reported that IL-33 augments T-bet and Blimp1, transcription factors crucial for $\mathrm{CD}^{+} \mathrm{T}$ cell [45].

IL-33 stimulates NKT and NK cells, provoking IFN- $\gamma$ production through IL-12 signaling [46]. In vitro, IL-33 increases NK cell cytotoxicity, and upregulated CD69 expression [46]. In animal models, transgenic expression of IL-33 augmented the accumulation of cytotoxic NK cells to the tumor tissue that inhibited metastasis formation [46]. Furthermore, augmented rates of CD107a ${ }^{+}$IFN- $\gamma^{+}$NK cells were described after IL-33 administration in spleens of B16 melanoma-bearing mice [47]. In contrast with these studies, investigations performed in breast cancer model demonstrated that IL-33/ST2 alters NK cell activation. ST2-deficient animals bearing breast tumors displayed augmented activated $\mathrm{NK}$ cells and NK cytotoxic activity and enhanced antitumor activity in ST2 ${ }^{-/-}$mice [48]. Moreover, exogenous administration of IL-33 to wild type breast tumor-bearing animals reduced NK cytotoxicity and increased cancer progression [49].

Mast cells (MC) are innate immune cells. MCs present the IL-33 receptor, and IL-33 stimulates MCs. However, whether IL-33 plays a role in MC survival remains to be proved. However, in skin-derived human MCs, IL-33 decreased MC apoptosis without modifying growth via the action of the antiapoptotic molecule B-cell lymphoma-X large [50].

Myeloid-derived suppressor cells (MDSCs) are lacking in normal subjects but increase in neoplastic diseases, where they have an immune-suppressive action [51]. Numerous works reported the capacity of IL-33 to increase MDSCs during the onset of tumors. In animal tumor models, IL-33 has been described to increase MDSC growth. IL-33 augmented the intratumoral increase of MDSCs that presented TGF- $\beta 1$ and IL-13 $\alpha 1$ R, while the absence of IL-33/ST2 signaling decreased the growth and the immunosuppressive capacity of MDSCs. Moreover, IL-33 increased activity of arginase- 1 in MDSCs and caused activation of MAPK and NF- $\mathrm{kB}$, with an increase of their immunosuppressive effects [52,53]. The action of IL-33 on all the effector cells reported above is partially due to its effecton cytokine production. It was demonstrated that IL-33 provokes production of several cytokines, including IL-4, IL-5, IL-6, IL-8, IL-10, IL-13, MIP-1 $\alpha$, IP-10, MCP-1, TNF, and GM-CSF [17,54,55] (Figure 3). 


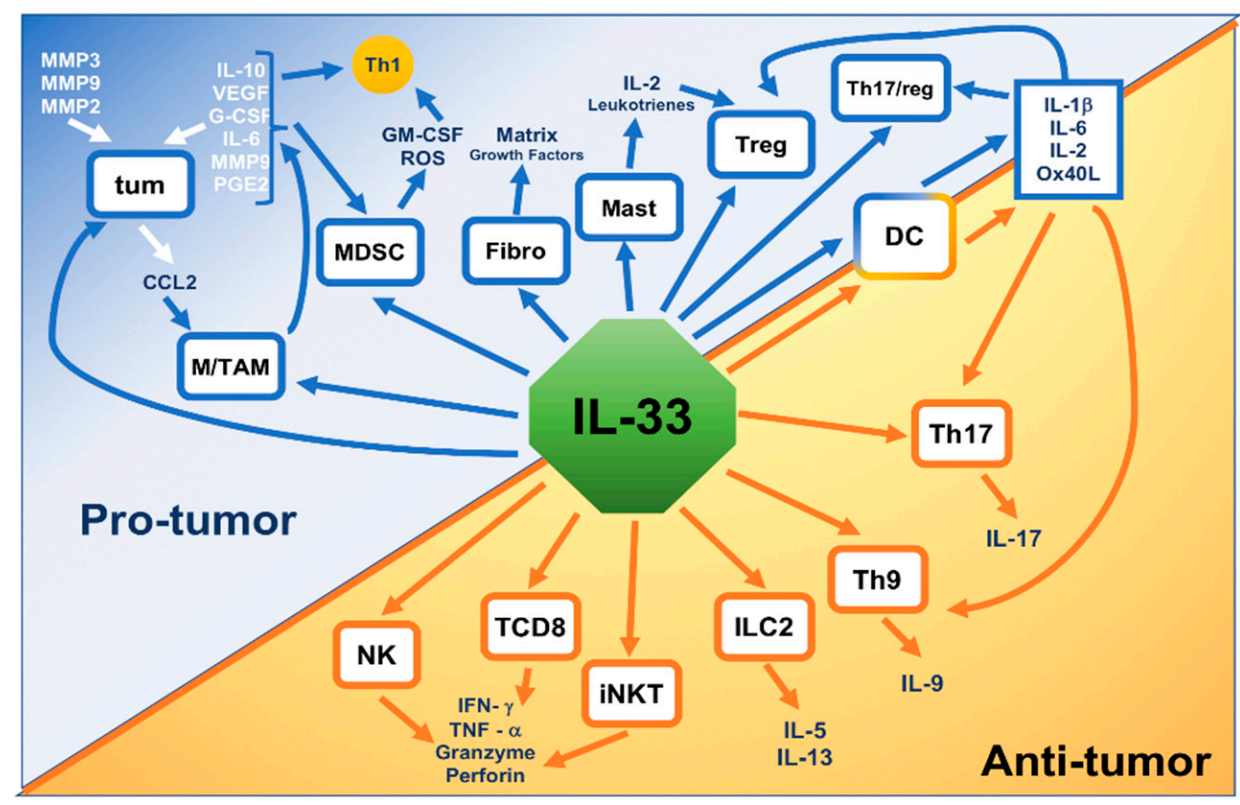

Figure 3. Dual role of IL-33 in cancer.IL-33 released in the TME is able to stimulate cancer cells (tum), fibroblasts (Fibro), and different immune cells (Macrophages, TAM, MDSC, mast cells, Treg, Dendritic Cells, Th 17, Th 9, Group 2 Innate lymphoid cells (ILC2), invariant Natural Killer cells (iNKT), CD8+ T cells, and Natural Killer cells) which are activated to produce molecules involved in protumor or antitumor processes leading to the development or to the regression of the tumor. Some cytokines produced by protumor cells such as myeloid-derived suppressor cells (MDSC) or Tumor-associated macrophages (TAM), are also able to produce cytokines which inhibit antitumor cells such as all the Th1 cells.

\subsection{IL-33 Action in Nonhematologic Malignancies}

The cancer microenvironment is a crucial factor for tumor onset. This milieu can be modified by several elements comprising pro- or antitumorigenic immune cells and cytokines [56].

Inflammation may have a protumorigenic activity. About $15 \%$ of cancers are linked to a conditions of chronic inflammation [57].

The alarmin IL-33 has been demonstrated to participate in several forms of inflammatory diseases and to influence tumorigenesis. Firstly, IL-33 was intended to be a procancer mediator, since the activation pathway of IL-33/ST2 could promote metastasis. After this first period, it emerged how by the activation of the immune system it could stimulate immune surveillance, thus exerting an antitumorigenic function $[58,59]$.

However, as far as this cytokine is concerned, we are faced with what has sometimes been defined as the IL-33 paradox. Several data have demonstrated a relevant role of IL-33 in numerous malignancies, where it may have both pro- and-less frequently—antitumorigenic actions [60,61].

Dependent on the cancer milieu, IL-33 may influence anticancer immunity, stimulating CD8-positive $\mathrm{T}$ cells essential for the elimination of tumor cells. Th17 and Treg cells are also immune modulators in cancer, and Th17 cells influence antitumor responses, while Treg cells have an action in the conservancy of self-tolerance and in the regulation of immune response to cancer cells [61]. Protumor action can also be exerted by the effect of the cytokine on MDSCs.

Some data have reported a positive association between IL-33 production in cancer cells and the best prognosis in tumor subjects, where IL-33 and ST2 concentrations were downregulated in cancer lung cells [62]. Moreover, plasma IL-33 concentrations were increased in the course of the early stage of lung carcinoma and reduced in the advanced stage of disease [63,64]. IL-33 levels were demonstrated to be a positive prognostic marker in hepatocellular carcinoma and in breast cancer cells $[65,66]$. IL-33, together with its receptor ST2, seems to play a key role in the tumor environment by involving different 
pathways, such as interferon regulatory factor-3 (IRF-3), MyD88, AKT, COT, ERK, and JNK.IL-33 may act in both a pro- and antioncogenic way by increasing cells' metabolism and by regulating the immune system [61,67] (Table 1).

Table 1. Pro/antitumorigenic role of IL-33 in hematological diseases.

\begin{tabular}{ccc}
\hline Disease & Model Used & Pro/Anti \\
\hline BCR-ABL1-negative myeloproliferative neoplasms neoplasms [68,69] & Cell lines Animal models & pro \\
Lymphomas [70-73] & Cell lines Mouse model Patients tissues & pro/anti \\
Acute myeloid leukemia [52,74-76] & Cell lines Animal models & anti \\
Chronic myeloid leukemia [68,77,78] & Cell lines Animal models & pro \\
MM bone disease [79-81] & Cell lines Patients tissues & anti \\
\hline
\end{tabular}

\section{IL-33 and Hematologic Malignancies}

\subsection{BCR-ABL1-Negative and Positive Myeloproliferative Neoplasms.}

Myeloproliferative neoplasms (MPNs) comprise a group of malignant hematopoietic conditions that consist of BCR-ABL1-negative diseases such as polycythemia Vera (PV), essential thrombocythemia (ET), and primary myelofibrosis (PMF), as well as BCR-ABL1-positive diseases such as chronic myelogenous leukemia (CML).

In an animal model of MPN, IL-33 has been demonstrated to have a crucial action in stimulating altered myelopoiesis. Animals that are homozygous for a mutant allele of inositol polyphosphate-5phosphatase D (Inpp5d), named styx, repeat the genesis of the MPN-like disease in Inpp5d knockout mice. Deficiency of MyD88 and Irak4 annulled disease progress. MyD88 and Irak4 transduce signals through Il-33, IL-1, and IL-18. Nevertheless, only the deletion of IL-33 was sufficient to re-establish normal hematopoiesis [68], while IL-33 produced from stromal cells increased the production of growth factors in bone marrow to cause myeloproliferation in mice. Augmented rates of IL-33-expressing cells were reported in bone samples from MPN subjects, and IL-33 administration stimulated colony formation by CD34+ MPN progenitor cells from patients [68]. Thus, IL-33 seems to be a crucial element in the onset and progression of MPN, although the interpretation of existing data is not easy to read. For instance, the role of IL-33 seems to be relevant for other specific chronic Philadelphia negative myeloproliferative diseases, but with a peculiar pattern. PV and ET patients had decreased plasma IL-33 levels that were thought to alter their immune system [69]. Probably, these difference could be explained by the hypersensitivity of MPN stem/progenitor cells to cytokines and growth factors, and it is plausible that even low amounts of secreted IL-33 within the niche may be sufficient to start a ST2-dependent inflammation that favors MPNs.

Regarding BCR-ABL1-positive myeloproliferative neoplasms, CD34+ cells from CML patients were targeted by IL-33. After IL-33 administration, these cells displayed an augmented expression of ST2, and an increased proliferation, while progenitor cells from control subjects did not and were insensitive to IL-33. Alteration of the IL-33/ST2 pathway was a result of the tyrosine kinase activity by the BCR-ABL1 oncogene. In experimental models, engraftment of CD34+ bone marrow progenitor cells from humans and animals expressing BCR-ABL1 was less effective in IL-33 knockout mice versus wild type animals, implying that IL-33 is essential for CD34+ progenitor proliferation [68,77].

ST2 overexpression is regularized after imatinib mesylate treatment, while IL-33 neutralizes in vitro imatinib mesylate-induced proliferation arrest in CML CD34 progenitors through activation of the STAT5 pathway. Concentrations of circulating soluble ST2, generally believed to be a functional sign of IL-33 signaling in vivo, correlate with disease load. The increased levels associated with a high Sokal score predictive of prognosis are normalized in CML subjects in molecular remission. Lastly, an effect of IL-33 on maintenance of CD34+ cells from CML subjects was demonstrated by using xenotransplant experiments in immunodeficient NOD Shi-SCID IL2R $\gamma \mathrm{c}^{\text {nul }}$ (NOG) mice [77]. These data demonstrated that CML cells were sensitive to IL-33, which was capable of sustaining proliferation and cytokine production both directly, indirectly by the expression of ST2, and by controlling the neoplastic microenvironment, suggesting a new therapeutic approach. 
Tare et al. identified a basophil-like chronic myelogenous leukemia cell line, KU812, that presents ST2L and has a response to IL-33 stimulation. IL-33 caused generation of several inflammatory mediators that were reduced by anti-ST2L and anti-IL-33 antibodies [78].

We must also consider that the IL-33/ST2 system in the BM can be stimulated both in hematopoietic cells and in stromal/nonhematopoietic cells. Activation of ST2 on these cells provokes the production of several cytokines (IL-6, GM-CSF, G-CSF, and IL-3) that can activate the STAT5 pathway and can cause resistance to imatinib mesylate [68,82].

Finally, the possible role played by IL-33 in the onset of side effects of tyrosine kinase inhibitors also appears to be of some interest. As reported in a previous case report belonging to our group, imatinib mesylate-related symptoms of dermatologic toxicities might be determined by the discharge of IL-33. In particular, it is possible that TKi treatment could provoke keratinocyte damage, the release of IL-33, and the successive contact of IL-33 with ST2 receptor on mast cells that causes the liberation of numerous factors able of causing skin lesions, comprising IL-31, a known pruritus-inducing cytokine [83].

While these results suggest a possible therapeutic advantage in stopping IL-33/ST2 signaling in MPNs, other studies should determine the role of this system for disease progression and drug resistance in MPN subjects. Another option could comprise a multitarget approach, involving IL-33 and ST2 blockade together with some other cytokines involved in the resistance pathway (IL-6, GM-CSF, G-CSF, and IL-3). It may be relevant in the future to address whether some in vitro experimental blockade could give some therapeutic advantages.

\subsection{Acute Myeloid Leukemia}

Although our comprehension of the possible immunotherapy approaches to treat acute myeloid leukemia (AML) is still growing, it is evident that leukemia cells have developed several diverse immunosuppressive activities to elude the antileukemia responses (increase of Tregs and MDSC, upregulation of programmed death 1 (PD-1) [84]. However, recent data demonstrated the main mechanism of the immune escape is the tolerance of leukemia-specific CD8+ T cells [85-88], and IL-33-mediated actions on leukemic cells could be due to CD8+ T cells and MDSC populations as speculated and demonstrated in other tumor experimental models [52,74].

Employment of recombinant IL-33 markedly reduces murine AML cell proliferation and increases survival. Notably, IL-33 administration licensed DCs from tumor-bearing mice to overwhelm the tolerance of leukemia-specific CD8+ T cells by causing expression of several costimulatory molecules. Moreover, IL-33 considerably augmented the effectiveness of PD-1 blockade, causing complete regression of disease in almost half of the treated animals. This suggests the possibility of a novel therapeutic approach of leukemia immunotherapy [75].

Studies have evaluated the existence of possible correlations between genetic alterations and the functioning of the ST2/IL33 system. In AML patients, chromosomal abnormalities have been reported. One of the most frequent alterations, inversion of chromosome 16 [inv (16)], produces the fusion oncogene CBFB-MYH11. This oncogene induces expression of IL1RL1. Employing Cbfb-MYH11 knock-in mice, it was reported that ST2 is present on cells with high leukemia stem cell activity. Moreover, $\mathrm{ST}_{2}{ }^{+}$cells can survive chemotherapy better than $\mathrm{ST}^{-}$cells in vivo [82]. Levescot et al. made a similar observation for BCR-ABL1 in CML [77]. The clinical significance of such data remains to be demonstrated.

IL-33 also stimulates basophilic differentiation in normal cells but appears to be more effective in patients with hematopoietic malignancies. Generally, basophil differentiation does not appear to depend on a specific growth factor or cytokine. Although IL-33 is a powerful driver of basophil differentiation in vitro, IL-33 knockout animals do not display an alteration in these cells. The expression of GATA2 is essential for appropriate basophil differentiation, but they are supposed to operate with other transcription elements, including GATA1 and STAT5 $[9,13,89]$. Acute basophilic leukemia (ABL) is an infrequent form of AML. In previous works, a recurrent $t(X ; 6)(\mathrm{p} 11 ; \mathrm{q} 23)$ translocation generating an MYB-GATA1 fusion gene was described in ABL patients. Cells presenting the chimeric MYB-GATA1 transcription factor displayed augmented expression of CD34 (a marker of immaturity) and of Fc RI 
and CD203c (markers of basophilic differentiation). IL-33 augmented the basophilic differentiation of MYB-GATA1-expressing cells, confirming the relevance of the ST2/IL-33 system in the basophilic differentiation of leukemic cells and CD34-positive primary cells [76]. Results showed that IL-33 effects in normal cells are rather modest and this suggests that this cytokine could be more effective in malignant cells than in normal ones, confirming once more the fundamental role of the IL-33/ST2 axis in hematologic malignancies.

\subsection{Lymphoproliferative Diseases}

The relevance of IL-33 in lymphoproliferative diseases has been demonstrated in animal models and studies conducted on human patients.

Genetic aberrations in Notch1 and Notch2 arise in B-cell neoplastic diseases such as Hodgkin lymphoma (HL), diffuse large B-cell lymphoma (DLBCL), chronic lymphocytic leukemia (CLL), follicular lymphoma (FL), and mantle cell lymphoma (MCL). B cells presenting altered Notch1 signaling have an immunomodulatory action on T cells by intensifying Th2 and Treg response in an IL-33-dependent manner. An experimental animal model, in which expression of Notch1 is provoked in B cells by AICDA gene promoter-driven CRE recombinase, demonstrated an increase of Th2 and Treg cells and a diminished production of cytokines by Th1 and CD8 T cells. Animals were more susceptible to tumors, indicating an altered antitumor T-cell capacity. This modified T-cell response was due to augmented IL-33 production by Notch1-activated B cells. Animals knockout of IL33 or the use of antibodies to block Il-33 annulled the Treg and Th2 cell response stimulated by B cells. Gene expression results obtained from patients affected by diffuse large B-cell lymphoma demonstrated that activated Notch signaling correlates positively with IL33 expression [70].

However, different experimental data seem to come from studies performed on Burkitt's lymphoma (Daudi cells) as demonstrated by the effect of IL-33 on $\gamma \delta \mathrm{T}$ lymphocytes. $\gamma \delta \mathrm{T}$ cells presenting the $\mathrm{V} \gamma 9 \mathrm{~T}$ cell receptor are the more represented $\gamma \delta \mathrm{T}$-cells in peripheral blood. After stimulation with phosphoantigens (PAg), these cells multiply and discharge proinflammatory cytokines, and drive cell cytotoxicity against several neoplastic diseases [71]. An increased production of PAgs by Burkitt's lymphomas mean that the neoplastic cells are identified and destroyed by the $\mathrm{V} \gamma 9 \mathrm{~T}$ cells $[90,91]$. IL-33 was able to provoke the in vitro growth of PAg-stimulated $V \gamma 9 \mathrm{~T}$ cells, which were displaying in vitro antitumor cytotoxicity. Human V $\gamma 9 \mathrm{~T}$ cells were expanded in vivo (in NSG mice) by IL-33. Hence, IL-33 could represent a substitute of IL-2 for V $\gamma 9$ T cell-based cancer immune treatments [72].

Regardinghuman patients with lymphoproliferative diseases, we evaluated the plasma concentrations of IL-33 in 77 subjects with B-CLL. There was a relevant variation between the CLL levels of IL-33 versus controls, with a reduction of IL-33 concentrations in patients. Moreover, there was a difference, although not statistically relevant, between the IL-33 concentrations in CLL subjects before and after treatment. Finally, a negative correlation between IL-33 and CD20 expression and a positive correlation between IL-33 and CD3 expression were also reported [92].

In LLC subjects, IL-33 seems to drive Th2 responses. Podhorecka et al. studied the Th1/Th2 balance in CLL subjects and proved the dominance of T type 1 cells and T cell-mediated immunity that is changed towards type 2 during the phase of disease progression [93]. The decrease in plasma concentrations of IL-33 might therefore justify the altered Th2 response described in these subjects [73]. Our study described the existence of an inverse correlation between plasma levels of IL-33 and CD20 expression, and IL-33 seems to be able to modify the expression of CD20. The exact mechanism leading to this process remains to be clarified [92].

Finally, the datum that the treatment of CLL provokes a normalization of IL-33 plasma concentrations suggests a direct role of the disease on the level of this cytokine. The contrasting data about IL-33 levels in patient serum could be both correlated to the rather short half-life of the molecule or to the fact that in some kinds of tumors it is secreted nearby its niche of near the neoplastic mass (i.e., lung cancer). Moreover, it should be considered the dual role of the alarmin, which on one side stimulates immune tolerance, on the other activates the proinflammatory cascade, giving rise to some oncogenic pathways. 


\subsection{Monoclonal Gammopathies}

There are numerous possible pathogenetic and therapeutic implications related to the role of IL-33 in patients with monoclonal gammopathies. For instance, our team investigated the plasma concentrations of IL-33 in 44 multiple myeloma (MM) subjects and 13 subjects with monoclonal gammopathy of undetermined significance (MGUS). IL-33 concentrations were statistically decreased in MM and MGUS subjects versus healthy controls. In MM subjects, a negative correlation between IL-33 level and stage was found [94].

Decreased IL-33 concentrations might justify the altered T response described in MM. Moreover, these data may imply that during disease evolution or the shift from a benign condition (MGUS) to a neoplastic condition (MM), the deficiency in cytokine production aggravates gradually, causing a further alteration of the immune responses [95].

IL-33 could have a role in bone disease of MM subjects. Different experiments demonstrated that in vitro IL-33 reduced osteoclast precursors' differentiation into mature osteoclasts and decreased their bone resorptive action. This datum is consistent with the hypothesis that IL-33 inhibits osteoclastogenesis [79,80], and is confirmed by other studies. For instance, it was described that curdlan, an agonist of dectin-1, reduces osteoclastogenesis. Zhu et al. reported that curdlan strongly reduced RANKL-induced osteoclast differentiation and bone resorption. Curdlan impeded the expression of nuclear factor of activated T-cells, cytoplasmic 1 (NFATc1), a crucial transcriptional factor for osteoclastogenesis. Remarkably, dectin-1 activation augmented the expression of Musculoaponeurotic Fibrosarcoma oncogene omolog B (MafB), an inhibitor of NFATc1, and IL-33 in osteoclast precursors. The same study demonstrated that IL-33 augmented the expression of MafB in osteoclast precursors and reduced the differentiation of osteoclast precursors into mature osteoclasts. Moreover, stopping ST2 partially abolished curdlan-induced inhibition of NFATc1 expression and osteoclast differentiation [81]. Once more, the paradoxical role of the IL-33 emerges, by enlightening its ability to block cell proliferation in particular situations in experimental models. However, blocking the IL-33/ST2 pathways in vitro could show its limits due to the different biological activity of the diverse in vivo IL-33 variants [96].

\section{Conclusions}

\subsection{Future Challenges and Perspectives}

IL-33 is a cytokine involved in the regulation of not only antitumor immunity but tumor growth. Immune responses can be activated by tumor growth via emitting danger signals [97]. Nevertheless, tumors progress by modifying the action of immune suppressive cells such as Treg and MDSc [98-100].

As noted in the previous paragraphs the pro- or antitumor role of cytokines varies according to the neoplastic pathology considered. In the field of hematological malignancies, the role of IL-33 seems even more complex. Although we can affirm the existence of a negative role of IL-33 in CML and in lymphoproliferative diseases and positive in pathologies like AML, the action of IL-33 seems to be multiple and sometimes contradictory within the same pathology. For example, in the course of MM, the reduction of IL-33 could harm the susceptibility to infections and a positive action on bone disease. However, we tried to give a clearer scenario by summarizing IL-33's potential role in hematological malignancies (Figure 4). In the future, we will have to learn to govern the negative aspects of activating the IL-33/ST2 axis and exploit the positive ones.

Upcoming studies on the effects of IL-33 on malignancies will probably focus on promotion of NK cell infiltration, group 2 innate lymphoid cells proliferation, and DC activation [101].

An intriguing topic will also be the nuclear function of IL-33. In fact, in addition to its extracellular role as an alarmin activating ST2 signaling, IL-33 also has a nuclear function [4]. This nuclear action of IL-33 may justify why some studies performed employing St2-deficient mice may not repeat the results from IL $33^{-/-}$animals. Furthermore, the study of the nuclear IL-33 action will be useful to evaluate the possible interactions with tumor-related transcription factors, and the modulation of nuclear IL-33 expression could represent a possible therapeutic approach. 


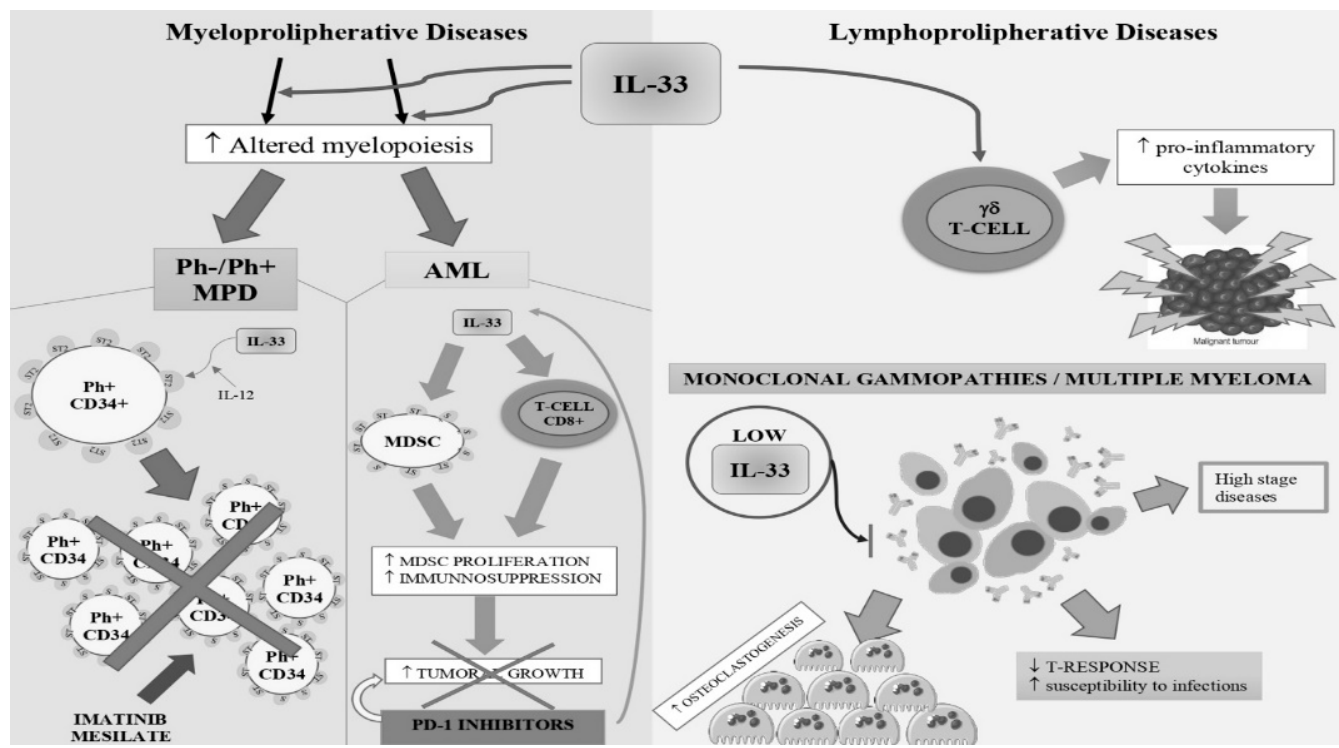

Figure 4. A summarizing scenario of IL-33's role in hematological malignancies. IL-33's pro- and antitumorigenic role is reported as follow. In MPN, IL-33 was demonstrated to have a crucial action in stimulating altered myelopoiesis. IL-33 increases the production of growth factors in bone marrow and causes myeloproliferation. As a consequence, there are augmented rates of IL-33+ in MPN subjects, and IL-33 administration stimulates colony formation from CD34+ MPN progenitor cells. In acute myeloid leukemia (AML), cells develop several diverse immunosuppressive activities to elude the antileukemia responses (increase of Tregs and MDSC, upregulation of programmed death 1 (PD-1). On the contrary, in lymphoproliferative diseases, augmented levels of the alarmin could favorite a proinflammatory response against the tumor. In multiple myeloma (MM), low levels of IL-33 are correlated with higher disease stages, minor T-response, and augmented osteoclastogenesis.

For its crucial role in tissue damage-induced tumorigenesis, IL-33 is a potential target, and diverse methods could be proposed to use or to target the cytokine. The employment of IL-33 as an adjuvant has been contemplated to regulate Th2 polarization [81]. Even in this case, however, prudence appears necessary due to the many target cells and the possibility to increase tumor progression in chronic myeloid malignancies. Neutralizing antibodies targeting IL-33 or ST2L could be utilized to reduce the activity of IL-33. However, in this area, their utilization may be checked due to the oxidation of cysteine residues and the existence of short-acting IL-33 within tissue microenvironments, with an underestimation of IL-33 concentrations due to an incapacity to evaluate IL-33 before degradation [102].

Moreover, therapeutic targeting of IL-33 may enhance the efficacy of the therapy with conventional treatment. For example, a sequence of imatinib and IL-33 blockade in CML may lead to eradication of cytokine-dependent malignant stem cells and avoid the appearance of drug resistance. In an experimental mouse model, the combination of IL-33 and PD-1 blockade was reported to enhance the survival of animals suffering from AML $[75,103]$.

A different field for a novel employment of IL-33 could be the vaccine therapy of neoplasms [104,105], as IL-33 works as a promoter of memory T cell immunity [106,107].

Finally, in the coming years, new methods of cytokine intervention will be developed. Ramadan et al. described several small-molecule ST2 inhibitors identified via a combination of high-throughput screening and computational analysis. After in vitro and in vivo toxicity evaluation, three molecules were chosen for validation in experimental GVHD models. The most effective molecule, iST2-1, decreases plasma sST2 concentrations, enhances survival, and preserves graft-versus-leukemia action [108]. Augmented circulating sST2 has been linked to pathological states. Evaluating this soluble molecule could be as important as dosing IL-33 in order to follow disease progression. Hematological malignancies are not an exception to this statement. Further studies on diverse and larger cohorts of patients should be considered in order to confirm their prognostic value. 
The introduction of the modulation of IL-33 activity into clinical practice is certainly still a premature hypothesis. However, the study of the effects of IL-33 on the different aspects of the physiopathology of hematological malignancies could help us to better understand the intimate mechanisms that regulate the onset and progression of these diseases and make their treatment easier.

Author Contributions: Conceptualization, A.A., C.M., S.G.; Formal analysis and data curation, V.I., G.T., G.P.; Writing—original draft preparation, A.A.; Writing—review and editing A.A., C.M., S.G., M.C.

Funding: This research received no external funding.

Conflicts of Interest: The authors declare no conflict of interest.

\section{References}

1. Krumm, B.; Xiang, Y.; Deng, J. Structural biology of the IL-1 superfamily: Key cytokines in the regulation of immune and inflammatory responses. Protein Sci. 2014, 23, 526-538. [CrossRef] [PubMed]

2. Cayrol, C.; Girard, J.P. Interleukin-33 (IL-33): A nuclear cytokine from the IL-1 family. Immunol. Rev. 2018, 281, 154-168. [CrossRef]

3. Liew, F.Y.; Girard, J.-P.; Turnquist, H.R. Interleukin-33 in health and disease. Nat. Rev. Immunol. 2016, 16, 676. [CrossRef] [PubMed]

4. Carriere, V.; Roussel, L.; Ortega, N.; Lacorre, D.-A.; Americh, L.; Aguilar, L.; Bouche, G.; Girard, J.-P. IL-33, the IL-1-like cytokine ligand for ST2 receptor, is a chromatin-associated nuclear factor in vivo. Proc. Natl. Acad. Sci. 2007, 104, 282-287. [CrossRef] [PubMed]

5. Moussion, C.; Ortega, N.; Girard, J.-P. The IL-1-like cytokine IL-33 is constitutively expressed in the nucleus of endothelial cells and epithelial cells in vivo: A novel 'alarmin'? PLoS ONE 2008, 3, e3331. [CrossRef]

6. Garlanda, C.; Dinarello, C.; Mantovani, A. The interleukin-1 family: Back to the future. Immunity 2013, 39, 1003-1018. [CrossRef]

7. Gajardo Carrasco, T.; Morales, R.A.; Pérez, F.; Terraza, C.; Yáñez, L.; Campos-Mora, M.; Pino-Lagos, K. Alarmin'immunologists: IL-33 as a putative target for modulating T cell-dependent responses. Front. Immunol. 2015, 6, 232. [CrossRef]

8. Byers, D.E.; Alexander-Brett, J.; Patel, A.C.; Agapov, E.; Dang-Vu, G.; Jin, X.; Wu, K.; You, Y.; Alevy, Y.; Girard, J.-P.; et al. Long-term IL-33-producing epithelial progenitor cells in chronic obstructive lung disease. J. Clin. Investig. 2013, 123, 3967-3982. [CrossRef]

9. Gordon, E.D.; Simpson, L.J.; Rios, C.L.; Ringel, L.; Lachowicz-Scroggins, M.E.; Peters, M.C.; WesolowskaAndersen, A.; Gonzalez, J.R.; MacLeod, H.J.; Christian, L.S.; et al. Alternative splicing of interleukin-33 and type 2 inflammation in asthma. Proc. Natl. Acad. Sci. USA 2016, 113, 8765-8770. [CrossRef]

10. Lefrançais, E.; Roga, S.; Gautier, V.; Gonzalez-de-Peredo, A.; Monsarrat, B.; Girard, J.-P.; Cayrol, C. IL-33 is processed into mature bioactive forms by neutrophil elastase and cathepsin G. Proc. Natl. Acad. Sci. USA 2012, 109, 1673-1678. [CrossRef]

11. Cayrol, C.; Girard, J.-P. The IL-1-like cytokine IL-33 is inactivated after maturation by caspase-1. Proc. Natl. Acad. Sci. USA 2009, 106, 9021-9026. [CrossRef] [PubMed]

12. Lüthi, A.U.; Cullen, S.P.; McNeela, E.A.; Duriez, P.J.; Afonina, I.S.; Sheridan, C.; Brumatti, G.; Taylor, R.C.; Kersse, K.; Vandenabeele, P.; et al. Suppression of interleukin-33 bioactivity through proteolysis by apoptotic caspases. Immunity 2009, 31, 84-98. [CrossRef] [PubMed]

13. Ali, S.; Nguyen, D.Q.; Falk, W.; Martin, M.U. Caspase 3 inactivates biologically active full length interleukin-33 as a classical cytokine but does not prohibit nuclear translocation. Biochem. Biophys. Res. Commun. 2010, 391, 1512-1516. [CrossRef] [PubMed]

14. Cohen, E.S.; Scott, I.C.; Majithiya, J.B.; Rapley, L.; Kemp, B.P.; England, E.; Rees, D.G.; Overed-Sayer, C.L.; Woods, J.; Bond, N.J.; et al. Oxidation of the alarmin IL-33 regulates ST2-dependent inflammation. Nat. Commun. 2015, 6, 8327. [CrossRef]

15. Hong, J.; Bae, S.; Jhun, H.; Lee, S.; Choi, J.; Kang, T.; Kwak, A.; Hong, K.; Kim, E.; Jo, S.; et al. Identification of constitutively active interleukin 33 (IL-33) splice variant. J. Biol. Chem. 2011, 286, 20078-20086. [CrossRef]

16. Tsuda, H.; Komine, M.; Karakawa, M.; Etoh, T.; Tominaga, S.; Ohtsuki, M. Novel splice variants of IL-33: Differential expression in normal and transformed cells. J. Investig. Dermatol. 2012, 132, 2661. [CrossRef] 
17. Smithgall, M.D.; Comeau, M.R.; Park Yoon, B.-R.; Kaufman, D.; Armitage, R.; Smith, D.E. IL-33 amplifies both Th1-and Th2-type responses through its activity on human basophils, allergen-reactive Th2 cells, iNKT and NK cells. Int. Immunol. 2008, 20, 1019-1030. [CrossRef]

18. Bartemes, K.R.; Iijima, K.; Kobayashi, T.; Kephart, G.M.; McKenzie, A.N.; Kita, H. IL-33-responsive lineage-CD25+CD44hi lymphoid cells mediate innate type 2 immunity and allergic inflammation in the lungs. J. Immunol. 2012, 188, 1503-1513. [CrossRef]

19. Lefrançais, E.; Duval, A.; Mirey, E.; Roga, S.; Espinosa, E.; Cayrol, C.; Girard, J.-P. Central domain of IL-33 is cleaved by mast cell proteases for potent activation of group-2 innate lymphoid cells. Proc. Natl. Acad. Sci. USA 2014, 111, 15502-15507. [CrossRef]

20. Yanagisawa, K.; Takagi, T.; Tsukamoto, T.; Tetsuka, T.; Tominaga, S. Presence of a novel primary response gene ST2L, encoding a product highly similar to the interleukin 1 receptor type 1 . FEBS Lett. 1993, 318, 83-87. [CrossRef]

21. Hardman, C.; Ogg, G. Interleukin-33, friend and foe in type-2 immune responses. Curr. Opin. Immunol. 2016, 42, 16-24. [CrossRef] [PubMed]

22. Bergers, G.; Reikerstorfer, A.; Braselmann, S.; Graninger, P.; Busslinger, M. Alternative promoter usage of the Fos-responsive gene Fit-1 generates mRNA isoforms coding for either secreted or membrane-bound proteins related to the IL-1 receptor. EMBO J. 1994, 13, 1176-1188. [CrossRef] [PubMed]

23. Tominaga, S.; Kuroiwa, K.; Tago, K.; Iwahana, H.; Yanagisawa, K.; Komatsu, N. Presence and expression of a novel variant form of ST2 gene product in human leukemic cell line UT-7/GM. Biochem. Biophys. Res. Commun. 1999, 264, 14-18. [CrossRef] [PubMed]

24. Tago, K.; Noda, T.; Hayakawa, M.; Iwahana, H.; Yanagisawa, K.; Yashiro, T.; Tominaga, S. Tissue distribution and subcellular localization of a variant form of the human ST2 gene product, ST2V. Biochem. Biophys. Res. Commun. 2001, 285, 1377-1383. [CrossRef]

25. Iwahana, H.; Hayakawa, M.; Kuroiwa, K.; Tago, K.; Yanagisawa, K.; Noji, S.; Tominaga, S. Molecular cloning of the chicken ST2 gene and a novel variant form of the ST2 gene product, ST2LV. Biochim. Biophys. Acta 2004, 1681, 1-14. [CrossRef]

26. Oshikawa, K.; Yanagisawa, K.; Tominaga, S.; Sugiyama, Y. Expression and function of the ST2 gene in a murine model of allergic airway inflammation. Clin. Exp. Allergy 2002, 32, 1520-1526. [CrossRef]

27. Iwahana, H.; Yanagisawa, K.; Ito-Kosaka, A.; Kuroiwa, K.; Tago, K.; Komatsu, N.; Katashima, R.; Itakura, M.; Tominaga, S. Different promoter usage and multiple transcription initiation sites of the interleukin-1 receptor-related human ST2 gene in UT-7 and TM12 cells. Eur. J. Biochem. 1999, 264, 397-406. [CrossRef]

28. Leung, B.P.; Xu, D.; Culshaw, S.; McInnes, I.B.; Liew, F.Y. A novel therapy of murine collagen-induced arthritis with soluble T1/ST2. J. Immunol. 2004, 173, 145-150. [CrossRef]

29. Hayakawa, H.; Hayakawa, M.; Kume, A.; Tominaga, S. Soluble ST2 blocks interleukin-33 signaling in allergic airway inflammation. J. Biol. Chem. 2007, 282, 26369-26380. [CrossRef]

30. Baba, Y.; Maeda, K.; Yashiro, T.; Inage, E.; Kasakura, K.; Suzuki, R.; Niyonsaba, F.; Hara, M.; Tanabe, A.; Ogawa, H.; et al. GATA2 Is a Critical Transactivator for the Human IL1RL1/ST2 Promoter in Mast Cells/Basophils OPPOSING ROLES FOR GATA2 and GATA1 IN HUMAN IL1RL1/ST2 GENE EXPRESSION. J. Biol. Chem. 2012, 287, 32689-32696. [CrossRef]

31. Liu, X.; Hammel, M.; He, Y.; Tainer, J.A.; Jeng, U.-S.; Zhang, L.; Wang, S.; Wang, X. Structural insights into the interaction of IL-33 with its receptors. Proc. Natl. Acad. Sci. 2013, 110, 14918-14923. [CrossRef] [PubMed]

32. Bourgeois, E.; van, L.P.; Samson, M.; Diem, S.; Barra, A.; Roga, S.; Gombert, J.M.; Schneider, E.; Dy, M.; Gourdy, P.; et al. The pro-Th2 cytokine IL-33 directly interacts with invariant NKT and NK cells to induce IFN- $\gamma$ production. Eur. J. Immunol. 2009, 39, 1046-1055. [CrossRef] [PubMed]

33. Bonilla, W.V.; Fröhlich, A.; Senn, K.; Kallert, S.; Fernandez, M.; Johnson, S.; Kreutzfeldt, M.; Hegazy, A.N.; Schrick, C.; Fallon, P.G.; et al. The alarmin interleukin-33 drives protective antiviral CD8+ T cell responses. Science 2012, 335, 984-989. [CrossRef] [PubMed]

34. Cayrol, C.; Girard, J.-P. IL-33: An alarmin cytokine with crucial roles in innate immunity, inflammation and allergy. Curr. Opin. Immunol. 2014, 31, 31-37. [CrossRef] [PubMed]

35. Xie, Y.; Akpinarli, A.; Maris, C.; Hipkiss, E.L.; Lane, M.; Kwon, E.-K.M.; Muranski, P.; Restifo, N.P.; Antony, P.A. Naive tumor-specific CD4+ T cells differentiated in vivo eradicate established melanoma. J. Exp. Med. 2010, 207, 651-667. [CrossRef] [PubMed] 
36. Hombach, A.; Köhler, H.; Rappl, G.; Abken, H. Human CD4+ T cells lyse target cells via granzyme/perforin upon circumvention of MHC class II restriction by an antibody-like immunoreceptor. J. Immunol. 2006, 177, 5668-5675. [CrossRef]

37. Komai-Koma, M.; Wang, E.; Kurowska-Stolarska, M.; Li, D.; McSharry, C.; Xu, D. Interleukin-33 promoting Th1 lymphocyte differentiation dependents on IL-12. Immunobiology 2016, 221, 412-417. [CrossRef]

38. Peine, M.; Marek, R.M.; Löhning, M. IL-33 in T Cell Differentiation, Function, and Immune Homeostasis. Trends Immunol. 2016, 37, 321-333. [CrossRef]

39. Griesenauer, B.; Paczesny, S. The ST2/IL-33 Axis in Immune Cells during Inflammatory Diseases. Front. Immunol. 2017, 8. [CrossRef]

40. Matta, B.M.; Lott, J.M.; Mathews, L.R.; Liu, Q.; Rosborough, B.R.; Blazar, B.R.; Turnquist, H.R. IL-33 Is an Unconventional Alarmin That Stimulates IL-2 Secretion by Dendritic Cells To Selectively Expand IL-33R/ST2+ Regulatory T Cells. J. Immunol. 2014, 193, 4010-4020. [CrossRef]

41. Schiering, C.; Krausgruber, T.; Chomka, A.; Frohlich, A.; Adelmann, K.; Wohlfert, E.A.; Pott, J.; Griseri, T.; Bollrath, J.; Hegazy, A.N.; et al. The alarmin IL-33 promotes regulatory T-cell function in the intestine. Nature 2014, 513, 564-568. [CrossRef] [PubMed]

42. He, Z.; Chen, L.; Souto, F.O.; Canasto-Chibuque, C.; Bongers, G.; Deshpande, M.; Harpaz, N.; Ko, H.M.; Kelley, K.; Furtado, G.C.; et al. Epithelial-derived IL-33 promotes intestinal tumorigenesis in Apc (Min/+) mice. Sci. Rep. 2017, 7, 5520. [CrossRef] [PubMed]

43. Meinicke, H.; Bremser, A.; Brack, M.; Akeus, P.; Pearson, C.; Bullers, S.; Hoffmeyer, K.; Stemmler, M.P.; Quiding-Jarbrink, M.; Izcue, A. Tumor-associated changes in intestinal epithelial cells cause local accumulation of KLRG1(+) GATA3(+) regulatory T cells in mice. Immunology 2017, 152, 74-88. [CrossRef] [PubMed]

44. Zhou, Y.; Ji, Y.; Wang, H.; Zhang, H.; Zhou, H. IL-33 Promotes the Development of Colorectal Cancer Through Inducing Tumor-Infiltrating ST2L(+) Regulatory T Cells in Mice. Technol. Cancer Res. Treat. 2018, 17, 1533033818780091. [CrossRef] [PubMed]

45. Yang, Q.; Li, G.; Zhu, Y.; Liu, L.; Chen, E.; Turnquist, H.; Zhang, X.; Finn, O.J.; Chen, X.; Lu, B. IL-33 synergizes with TCR and IL-12 signaling to promote the effector function of CD8+ T cells. Eur. J. Immunol. 2011, 41, 3351-3360. [CrossRef]

46. Gao, K.; Li, X.; Zhang, L.; Bai, L.; Dong, W.; Gao, K.; Shi, G.; Xia, X.; Wu, L.; Zhang, L. Transgenic expression of IL-33 activates CD8(+) T cells and NK cells and inhibits tumor growth and metastasis in mice. Cancer Lett. 2013, 335, 463-471. [CrossRef]

47. Lucarini, V.; Ziccheddu, G.; Macchia, I.; La Sorsa, V.; Peschiaroli, F.; Buccione, C.; Sistigu, A.; Sanchez, M.; Andreone, S.; D'Urso, M.T.; et al. IL-33 restricts tumor growth and inhibits pulmonary metastasis in melanoma-bearing mice through eosinophils. Oncoimmunology 2017, 6, e1317420. [CrossRef]

48. Jovanovic, I.; Radosavljevic, G.; Mitrovic, M.; Juranic, V.L.; McKenzie, A.N.J.; Arsenijevic, N.; Jonjic, S.; Lukic, M.L. ST2 deletion enhances innate and acquired immunity to murine mammary carcinoma. Eur. J. Immunol. 2011, 41, 1902-1912. [CrossRef]

49. Jovanovic, I.P.; Pejnovic, N.N.; Radosavljevic, G.D.; Pantic, J.M.; Milovanovic, M.Z.; Arsenijevic, N.N.; Lukic, M.L. Interleukin-33/ST2 axis promotes breast cancer growth and metastases by facilitating intratumoral accumulation of immunosuppressive and innate lymphoid cells. Int. J. Cancer 2014, 134, 1669-1682. [CrossRef]

50. Wang, J.X.; Kaieda, S.; Ameri, S.; Fishgal, N.; Dwyer, D.; Dellinger, A.; Kepley, C.L.; Gurish, M.F.; Nigrovic, P.A. IL-33/ST2 axis promotes mast cell survival via BCLXL. Proc. Natl. Acad. Sci. USA 2014, 111, 10281-10286. [CrossRef]

51. Musolino, C.; Allegra, A.; Pioggia, G.; Gangemi, S. Immature myeloid-derived suppressor cells: A bridge between inflammation and cancer (Review). Oncol. Rep. 2017, 37, 671-683. [CrossRef]

52. Xiao, P.; Wan, X.; Cui, B.; Liu, Y.; Qiu, C.; Rong, J.; Zheng, M.; Song, Y.; Chen, L.; He, J.; et al. Interleukin 33 in tumor microenvironment is crucial for the accumulation and function of myeloid-derived suppressor cells. Oncoimmunology 2016, 5, e1063772. [CrossRef] [PubMed]

53. Tcyganov, E.; Mastio, J.; Chen, E.; Gabrilovich, D.I. Plasticity of myeloid-derived suppressor cells in cancer. Curr. Opin. Immunol. 2018, 51, 76-82. [CrossRef] [PubMed]

54. Allakhverdi, Z.; Smith, D.E.; Comeau, M.R.; Delespesse, G. Cutting edge: The ST2 ligand IL-33 potently activates and drives maturation of human mast cells. J. Immunol. 2007, 179, 2051-2054. [CrossRef] [PubMed]

55. Pecaric-Petkovic, T.; Didichenko, S.A.; Kaempfer, S.; Spiegl, N.; Dahinden, C.A. Human basophils and eosinophils are the direct target leukocytes of the novel IL-1 family member IL-33. Blood 2009, 113, 1526-1534. [CrossRef] 
56. Mantovani, A.; Allavena, P.; Sica, A.; Balkwill, F. Cancer-related inflammation. Nature 2008, 454, 436-444. [CrossRef]

57. Kim, S.; Karin, M. Role of TLR2-dependent inflammation in metastatic progression. Ann. N. Y. Acad. Sci. 2011, 1217, 191-206. [CrossRef]

58. Wasmer, M.-H.; Krebs, P. The Role of IL-33-Dependent Inflammation in the Tumor Microenvironment. Front. Immunol. 2016, 7, 682. [CrossRef]

59. Afferni, C.; Buccione, C.; Andreone, S.; Galdiero, M.R.; Varricchi, G.; Marone, G.; Mattei, F.; Schiavoni, G. The Pleiotropic Immunomodulatory Functions of IL-33 and Its Implications in Tumor Immunity. Front. Immunol. 2018, 9, 2601. [CrossRef]

60. Lu, B.; Yang, M.; Wang, Q. Interleukin-33 in tumorigenesis, tumor immune evasion, and cancer immunotherapy. J. Mol. Med. 2016, 94, 535-543. [CrossRef]

61. Casciaro, M.; Cardia, R.; Di Salvo, E.; Tuccari, G.; Ieni, A.; Gangemi, S. Interleukin-33 Involvement in Nonsmall Cell Lung Carcinomas: An Update. Biomolecules 2019, 9. [CrossRef] [PubMed]

62. Yang, M.; Feng, Y.; Yue, C.; Xu, B.; Chen, L.; Jiang, J.; Lu, B.; Zhu, Y. Lower expression level of IL-33 is associated with poor prognosis of pulmonary adenocarcinoma. PLoS ONE 2018, 13, e0193428. [CrossRef] [PubMed]

63. Kim, M.S.; Kim, E.; Heo, J.S.; Bae, D.J.; Lee, J.U.; Lee, T.H.; Lee, H.J.; Chang, H.S.; Park, J.S.; Jang, A.S.; et al. Circulating IL-33 level is associated with the progression of lung cancer. Lung Cancer 2015, 90, 346-351. [CrossRef] [PubMed]

64. Hsu, Y.-L.; Hung, J.-Y.; Lee, Y.-L.; Chen, F.-W.; Chang, K.-F.; Chang, W.-A.; Tsai, Y.-M.; Chong, I.-W.; Kuo, P.-L. Identification of novel gene expression signature in lung adenocarcinoma by using next-generation sequencing data and bioinformatics analysis. Oncotarget 2017, 8, 104831-104854. [CrossRef] [PubMed]

65. Brunner, S.M.; Rubner, C.; Kesselring, R.; Martin, M.; Griesshammer, E.; Ruemmele, P.; Stempfl, T.; Teufel, A.; Schlitt, H.J.; Fichtner-Feigl, S. Tumor-infiltrating, interleukin-33-producing effector-memory CD8(+) T cells in resected hepatocellular carcinoma prolong patient survival. Hepatology 2015, 61, 1957-1967. [CrossRef] [PubMed]

66. Jafarzadeh, A.; Minaee, K.; Farsinejad, A.R.; Nemati, M.; Khosravimashizi, A.; Daneshvar, H.; Mohammadi, M.M.; Sheikhi, A.; Ghaderi, A. Evaluation of the circulating levels of IL-12 and IL-33 in patients with breast cancer: Influences of the tumor stages and cytokine gene polymorphisms. Iran J. Basic Med. Sci. 2015, 18, 1189-1198.

67. Liew, F.Y.; Pitman, N.I.; McInnes, I.B. Disease-associated functions of IL-33: The new kid in the IL-1 family. Nat. Rev. Immunol. 2010, 10, 103-110. [CrossRef]

68. Mager, L.F.; Riether, C.; Schurch, C.M.; Banz, Y.; Wasmer, M.H.; Stuber, R.; Theocharides, A.P.; Li, X.; Xia, Y.; Saito, H.; et al. IL-33 signaling contributes to the pathogenesis of myeloproliferative neoplasms. J. Clin. Investig. 2015, 125, 2579-2591. [CrossRef]

69. Gangemi, S.; Allegra, A.; Profita, M.; Saitta, S.; Gerace, D.; Bonanno, A.; Alonci, A.; Petrungaro, A.; Russo, S.; Musolino, C. Decreased plasma levels of IL-33 could contribute to the altered function of Th2 lymphocytes in patients with polycythemia vera and essential thrombocythemia. Cancer Investig. 2013, 31, 212-213. [CrossRef]

70. Arima, H.; Nishikori, M.; Otsuka, Y.; Kishimoto, W.; Izumi, K.; Yasuda, K.; Yoshimoto, T.; Takaori-Kondo, A. B cells with aberrant activation of Notch1 signaling promote Treg and Th2 cell-dominant T-cell responses via IL-33. Blood Adv. 2018, 2, 2282-2295. [CrossRef]

71. Kabelitz, D.; Wesch, D.; Pitters, E.; Zoller, M. Characterization of tumor reactivity of human V gamma 9V delta 2 gamma delta T cells in vitro and in SCID mice in vivo. J. Immunol. 2004, 173, 6767-6776. [CrossRef]

72. Duault, C.; Betous, D.; Bezombes, C.; Roga, S.; Cayrol, C.; Girard, J.P.; Fournie, J.J.; Poupot, M. IL-33-expanded human Vgamma9Vdelta2 T cells have anti-lymphoma effect in a mouse tumor model. Eur. J. Immunol. 2017, 47, 2137-2141. [CrossRef] [PubMed]

73. Huang, L.; Chen, S.; Zha, X.; Yang, L.; Li, B.; Yu, Z.; Wang, L.; Li, Y. Expression feature of CD3, FcepsilonRIgamma, and Zap-70 in patients with chronic lymphocytic leukemia. Hematology 2012, 17, 71-75. [CrossRef] [PubMed]

74. Gao, X.; Wang, X.; Yang, Q.; Zhao, X.; Wen, W.; Li, G.; Lu, J.; Qin, W.; Qi, Y.; Xie, F.; et al. Tumoral expression of IL-33 inhibits tumor growth and modifies the tumor microenvironment through CD8+ T and NK cells. J. Immunol. 2015, 194, 438-445. [CrossRef] [PubMed]

75. Qin, L.; Dominguez, D.; Chen, S.; Fan, J.; Long, A.; Zhang, M.; Fang, D.; Zhang, Y.; Kuzel, T.M.; Zhang, B. Exogenous IL-33 overcomes T cell tolerance in murine acute myeloid leukemia. Oncotarget 2016, 7, 61069-61080. [CrossRef] [PubMed] 
76. Ducassou, S.; Prouzet-Mauleon, V.; Deau, M.C.; Brunet de la Grange, P.; Cardinaud, B.; Soueidan, H.; Quelen, C.; Brousset, P.; Pasquet, J.M.; Moreau-Gaudry, F.; et al. MYB-GATA1 fusion promotes basophilic leukemia: Involvement of interleukin-33 and nerve growth factor receptors. J. Pathol. 2017, 242, 347-357. [CrossRef]

77. Levescot, A.; Flamant, S.; Basbous, S.; Jacomet, F.; Féraud, O.; Anne Bourgeois, E.; Bonnet, M.-L.; Giraud, C.; Roy, L.; Barra, A.; et al. BCR-ABL-Induced Deregulation of the IL-33/ST2 Pathway in CD34(+) Progenitors from Chronic Myeloid Leukemia Patients. Cancer Res. 2014, 74, 2669-2676. [CrossRef]

78. Tare, N.; Li, H.; Morschauser, A.; Cote-Sierra, J.; Ju, G.; Renzetti, L.; Lin, T.A. KU812 cells provide a novel in vitro model of the human IL-33/ST2L axis: Functional responses and identification of signaling pathways. Exp. Cell Res. 2010, 316, 2527-2537. [CrossRef]

79. Saleh, H.; Eeles, D.; Hodge, J.M.; Nicholson, G.C.; Gu, R.; Pompolo, S.; Gillespie, M.T.; Quinn, J.M. Interleukin-33, a target of parathyroid hormone and oncostatin $\mathrm{m}$, increases osteoblastic matrix mineral deposition and inhibits osteoclast formation in vitro. Endocrinology 2011, 152, 1911-1922. [CrossRef]

80. Schulze, J.; Bickert, T.; Beil, F.T.; Zaiss, M.M.; Albers, J.; Wintges, K.; Streichert, T.; Klaetschke, K.; Keller, J.; Hissnauer, T.N.; et al. Interleukin-33 is expressed in differentiated osteoblasts and blocks osteoclast formation from bone marrow precursor cells. J. Bone Miner. Res. 2011, 26, 704-717. [CrossRef]

81. Zhu, X.; Zhao, Y.; Jiang, Y.; Qin, T.; Chen, J.; Chu, X.; Yi, Q.; Gao, S.; Wang, S. Dectin-1 signaling inhibits osteoclastogenesis via IL-33-induced inhibition of NFATc1. Oncotarget 2017, 8, 53366-53374. [CrossRef] [PubMed]

82. Wang, Y.; Richter, L.; Becker, M.; Amador, C.; Hyde, R.K. IL1RL1 is dynamically expressed on Cbfb-MYH11(+) leukemia stem cells and promotes cell survival. Sci. Rep. 2019, 9, 1729. [CrossRef]

83. Musolino, C.; Allegra, A.; Mannucci, C.; Russo, S.; Alonci, A.; Maisano, V.; Calapai, G.; Gangemi, S. Possible Role of Interleukin-31/33 Axis in Imatinib Mesylate-Associated Skin Toxicity. Turk. J. Haematol. 2015, 32, 168-171. [CrossRef] [PubMed]

84. Curran, E.; Corrales, L.; Kline, J. Targeting the innate immune system as immunotherapy for acute myeloid leukemia. Front. Oncol. 2015, 5, 83. [CrossRef] [PubMed]

85. Staveley-O'Carroll, K.; Sotomayor, E.; Montgomery, J.; Borrello, I.; Hwang, L.; Fein, S.; Pardoll, D.; Levitsky, H. Induction of antigen-specific T cell anergy: An early event in the course of tumor progression. Proc. Natl. Acad. Sci. USA 1998, 95, 1178-1183. [CrossRef]

86. Sotomayor, E.M.; Borrello, I.; Rattis, F.M.; Cuenca, A.G.; Abrams, J.; Staveley-O'Carroll, K.; Levitsky, H.I. Cross-presentation of tumor antigens by bone marrow-derived antigen-presenting cells is the dominant mechanism in the induction of T-cell tolerance during B-cell lymphoma progression. Blood 2001, 98, 1070-1077. [CrossRef]

87. Chen, X.; Kline, D.E.; Kline, J. Peripheral T-cell tolerance in hosts with acute myeloid leukemia. Oncoimmunology 2013, 2, e25445. [CrossRef]

88. Zhang, L.; Chen, X.; Liu, X.; Kline, D.E.; Teague, R.M.; Gajewski, T.F.; Kline, J. CD40 ligation reverses T cell tolerance in acute myeloid leukemia. J. Clin. Investig. 2013, 123, 1999-2010. [CrossRef]

89. Cassel, S.L.; Joly, S.; Sutterwala, F.S. The NLRP3 inflammasome: A sensor of immune danger signals. Semin. Immunol. 2009, 21, 194-198. [CrossRef]

90. Gober, H.J.; Kistowska, M.; Angman, L.; Jeno, P.; Mori, L.; De Libero, G. Human T cell receptor gammadelta cells recognize endogenous mevalonate metabolites in tumor cells. J. Exp. Med. 2003, 197, 163-168. [CrossRef]

91. Hebbeler, A.M.; Cairo, C.; Cummings, J.S.; Pauza, C.D. Individual Vgamma2-Jgamma1.2+ T cells respond to both isopentenyl pyrophosphate and Daudi cell stimulation: Generating tumor effectors with low molecular weight phosphoantigens. Cancer Immunol. Immunother. 2007, 56, 819-829. [CrossRef] [PubMed]

92. Musolino, C.; Allegra, A.; Profita, M.; Alonci, A.; Saitta, S.; Bonanno, A.; Gerace, D.; Calabro, L.; Gangemi, S. Reduction in IL-33 plasma levels might be involved in T cell dysregulation in chronic lymphocytic leukemia. Acta Hematol. 2014, 131, 165-166. [CrossRef] [PubMed]

93. Podhorecka, M.; Dmoszynska, A.; Rolinski, J.; Wasik, E. T type 1/type 2 subsets balance in B-cell chronic lymphocytic leukemia-the three-color flow cytometry analysis. Leuk. Res. 2002, 26, 657-660. [CrossRef]

94. Musolino, C.; Allegra, A.; Profita, M.; Alonci, A.; Saitta, S.; Russo, S.; Bonanno, A.; Innao, V.; Gangemi, S. Reduced IL-33 plasma levels in multiple myeloma patients are associated with more advanced stage of disease. Br. J. Haematol. 2013, 160, 709-710. [CrossRef] [PubMed] 
95. Wang, S.; Hong, S.; Wezeman, M.; Qian, J.; Yang, J.; Yi, Q. Dendritic cell vaccine but not idiotype-KLH protein vaccine primes therapeutic tumor-specific immunity against multiple myeloma. Front. Biosci. 2007, 12, 3566-3575. [CrossRef] [PubMed]

96. Larsen, K.M.; Minaya, M.K.; Vaish, V.; Peña, M.M.O. The Role of IL-33/ST2 Pathway in Tumorigenesis. Int. J. Mol. Sci. 2018, 19, 2676. [CrossRef] [PubMed]

97. Galon, J.; Costes, A.; Sanchez-Cabo, F.; Kirilovsky, A.; Mlecnik, B.; Lagorce-Pages, C.; Tosolini, M.; Camus, M.; Berger, A.; Wind, P.; et al. Type, density, and location of immune cells within human colorectal tumors predict clinical outcome. Science 2006, 313, 1960-1964. [CrossRef]

98. Fridlender, Z.G.; Sun, J.; Kim, S.; Kapoor, V.; Cheng, G.; Ling, L.; Worthen, G.S.; Albelda, S.M. Polarization of tumor-associated neutrophil phenotype by TGF-beta: “N1" versus “N2” TAN. Cancer Cell 2009, 16, 183-194. [CrossRef]

99. Rosenberg, S.A.; Yang, J.C.; Sherry, R.M.; Kammula, U.S.; Hughes, M.S.; Phan, G.Q.; Citrin, D.E.; Restifo, N.P.; Robbins, P.F.; Wunderlich, J.R.; et al. Durable complete responses in heavily pretreated patients with metastatic melanoma using T-cell transfer immunotherapy. Clin. Cancer Res. 2011, 17, 4550-4557. [CrossRef]

100. Chen, L.J.; Zheng, X.; Shen, Y.P.; Zhu, Y.B.; Li, Q.; Chen, J.; Xia, R.; Zhou, S.M.; Wu, C.P.; Zhang, X.G.; et al. Higher numbers of T-bet(+) intratumoral lymphoid cells correlate with better survival in gastric cancer. Cancer Immunol. Immunother. 2013, 62, 553-561. [CrossRef]

101. Shen, J.X.; Liu, J.; Zhang, G.J. Interleukin-33 in Malignancies: Friends or Foes? Front. Immunol. $2018,9,3051$. [CrossRef] [PubMed]

102. Schwartz, C.; O'Grady, K.; Lavelle, E.C.; Fallon, P.G. Interleukin 33: An innate alarm for adaptive responses beyond Th2 immunity-emerging roles in obesity, intestinal inflammation, and cancer. Eur. J. Immunol. 2016, 46, 1091-1100. [CrossRef] [PubMed]

103. Corbin, A.S.; Agarwal, A.; Loriaux, M.; Cortes, J.; Deininger, M.W.; Druker, B.J. Human chronic myeloid leukemia stem cells are insensitive to imatinib despite inhibition of BCR-ABL activity. J. Clin. Investig. 2011, 121, 396-409. [CrossRef] [PubMed]

104. Allegra, A.; Penna, G.; Innao, V.; Greve, B.; Maisano, V.; Russo, S.; Musolino, C. Vaccination of multiple myeloma: Current strategies and future prospects. Crit. Rev. Oncol. Hematol. 2015, 96, 339-354. [CrossRef] [PubMed]

105. Allegra, A.; Russo, S.; Gerace, D.; Calabro, L.; Maisano, V.; Innao, V.; Musolino, C. Vaccination strategies in lymphoproliferative disorders: Failures and successes. Leuk. Res. 2015, 39, 1006-1019. [CrossRef]

106. Villarreal, D.O.; Wise, M.C.; Walters, J.N.; Reuschel, E.L.; Choi, M.J.; Obeng-Adjei, N.; Yan, J.; Morrow, M.P.; Weiner, D.B. Alarmin IL-33 acts as an immunoadjuvant to enhance antigen-specific tumor immunity. Cancer Res. 2014, 74, 1789-1800. [CrossRef]

107. Kojima, R.; Scheller, L.; Fussenegger, M. Nonimmune cells equipped with T-cell-receptor-like signaling for cancer cell ablation. Nat. Chem. Biol. 2018, 14, 42-49. [CrossRef]

108. Ramadan, A.M.; Daguindau, E.; Rech, J.C.; Chinnaswamy, K.; Zhang, J.; Hura, G.L.; Griesenauer, B.; Bolten, Z.; Robida, A.; Larsen, M.; et al. From proteomics to discovery of first-in-class ST2 inhibitors active in vivo. JCI Insight 2018, 3. [CrossRef]

(C) 2019 by the authors. Licensee MDPI, Basel, Switzerland. This article is an open access article distributed under the terms and conditions of the Creative Commons Attribution (CC BY) license (http://creativecommons.org/licenses/by/4.0/). 